\title{
15 Trends in Economic History Writing of Early South Asia
}

\section{Introduction}

Economic history writing in India had its origin in the controversies over the effects of British rule and its consequences for the Indian economy. ${ }^{1}$ Within the first three decades of the twentieth century, it became an established discipline, with economic processes in the ancient period also receiving some attention. This essay will present the major trends of economic history writing within the wider context of Indian historiographical traditions. ${ }^{2}$

Indian historiography experienced several phases of dominant schools of history writing: imperialist/colonial, nationalist, Marxist, post-structural, postcolonial, etc. However, a strict evolutionary account of schools of historical scholarship would be inappropriate. First, it would assume that these schools were successive to one another, and may give an impression of hidden commonalities running through all these modes of historiography. Second, it would obscure many overlaps among these schools. Third, some practitioners have continued to work with a method deemed obsolete by fellow historians and, fourth, it would elide the question of why particular positions or methods were more stable than others. ${ }^{3}$ Considering these problems, the current chapter attempts to chart out the trends in history writing of India without assuming a chronological succession of different schools of thought.

\section{Beginnings and Developments in History Writing}

\section{II.1 The Scientific West and the (Missing) History of India}

The aim of the earliest enthusiasts of the Indian past was to make India legible to the West. In this process, colonial and scientific motives became merged, making it

\footnotetext{
1 Habib 2009, 3; Seshan 2007, 164-166. The earliest works included various essays and monographs by M. G. Ranade (1842-1901, one of the founding members of the National Congress Party), Dadabhai Naoroji (1825-1917, Parsi scholar and Liberal Party member of the British Parliament) and Romesh C. Dutt (1848-1909, civil servant).

2 Morris and Stein 1961; Sharma and Jha 1974; Chakravarti 2001; Chattopadhyaya 2003, 217-232; Ray 2011; Basant 2012, 4-54.

3 For further discussions on issues of historiography, see Chattopadhyaya 2003, 3-4; Seshan 2007, 158-160.
}

Ә Open Access. () 2020 Mamta Dwivedi, published by De Gruyter. (c) BY-NC-ND This work is licensed under the Creative Commons Attribution-NonCommercial-NoDerivatives 4.0 License.

https://doi.org/10.1515/9783110607741-024 
difficult to distinguish between the two. ${ }^{4}$ Some notions and understandings of the Indian people and their religion had already interested Western audiences through the works of the Jesuits, followed by the Dutch and German Protestants. Already before the administration of India under the British East India Company, three comprehensive Sanskrit grammars had been produced in the seventeenth and eighteenth centuries by Jesuit missionaries. ${ }^{5}$ In the 1770 s Governor General Warren Hastings provided the impetus for the production of Orientalist knowledge, aiming to understand the laws, norms, and customs of the natives. His Judicial Plan of 1772 resolved to adhere to laws in "the Shaster with respect to Gentoos" and "Koran with respect of Mahometans." 6 This was the period when ancient texts were explored, and Indologists interested in knowing about India's past translated many works. Hastings's patronage of the production of the Purānārthaprakāśa, an abstract of history from the Sanskrit purānas, in 1784 was a clear move toward it. ${ }^{7}$ The aim was to bring forth the true and pristine understanding of the past as presented in the ancient books.

Inquiries into the Indian past by Western antiquarians and scholars started through individuals' interests in exploring material treasures and cultural difference. They started with translation exercises and geographical surveys, and eventually developed history writing as an institutional field of inquiry. Modern academic disciplines, especially philology and archaeology, were introduced in order to understand India's historical past. They took a more organized form with the formation of the Asiatic Society (1784) under the presidency of William Jones at Calcutta. From 1788, the Society published its transactions, called Asiatick Researches, which were to appeal to all the "naturalists, chemists, antiquaries, philologers, and men of sciences from different parts of Asia" to "commit their observations to writing, and sending them to the Asiatic Society at Calcutta."8 However, to the enthusiasts of factual history, the purānas soon appeared to be disappointing because of their lack of credible history. The succession of kings that was extracted from the purānas had no place in Western historical chronologies, as the Indic concept of time could not be linked to Western concept of history and chronology. To the Western minds of the eighteenth century, for whom the world was only a few thousand years old, references to millions of years in Indian traditional chronologies seemed useless. ${ }^{9}$

4 Trautmann and Sinopoli 2002, 494.

5 The three complete Sanskrit grammars were composed by Fathers Heinrich Roth (1620-1668), Johann Ernst Hanxleden (1681-1732) and Jean-François Pons (1698-1752?). These have been preserved in European libraries and monasteries as the earliest tangible products of cross-cultural and intellectual interchange (Van Hal 2016, 99).

6 Rocher 1994, 220-221.

7 Trautmann and Sinopoli 2002, 496; Rocher 1983, 48-72.

8 These words of William Jones became the credo of the Asiatic Society. This was quoted on the cover pages of the Journal of the Asiatic Society of Bengal.

9 Trautmann 2009 25-52, 155-188. It was with the time revolution of the 1850s and 1860s, along with Charles Darwin's works (1859 and 1871) on the theory of evolution, that the proposed human 
The early nineteenth-century scholars were baffled and simultaneously disenchanted by the disparity they saw between the material remains and the descriptions in the texts. This became the main reason for early antiquarians to declare that Indians lacked a "sense of history." The fact that ancient Indian literature failed to establish a political chronology that could be tested against and corroborated by the Western chronology led them to refer to the texts as unhistorical and mythological. ${ }^{10}$ James Mill's 1817 History of British India made a strong case for justifying British rule in India by referring to Indian stagnation and inability to change. Furthermore, the works of Max Müller in the 1850s, including A History of Ancient Sanskrit Literature in 1859, had put forward the image that Indians were unconcerned with the material world and that their thoughts and ideas were focused more toward the religious and transcendental sphere. The indigenous literary texts are described as "religious and semi-religious," which "threw only a very dim light on secular affairs." 11 Their value as historical sources was further reduced because their composition could not be assigned to any single period in time. ${ }^{12}$ In all, this pointed to a lack of scientific temperament and spirit of enterprise. The scientific and dynamic Occident had come into contact with a stagnant and religious Orient. This idea was reiterated in the new educational policy under Governor General William Bentinck during his office between 1828 and 1836. He favored Western knowledge over indigenous forms of learning, and thus the government funding for printing ancient texts almost stopped. ${ }^{13}$

The image of a stagnant and primarily rural India gained further currency from the mid-nineteenth century onward with Karl Marx's conceptualization of the Asiatic mode of production. ${ }^{14}$ India served as a fine example through which he explained it. Among the characteristics of the Asiatic mode of production were the absence of private ownership of land, as all land was state owned; the predominance of village economy with occasional towns functioning more as military camps or administrative centers than commercial hubs; self-sufficient and closed village economies meeting their own agricultural needs and manufacturing essential goods; a lack of surplus for exchange, fostered by the state that collected large shares of the surplus used by a despotic ruler for his luxurious life; complete subjugation of rural communities; and control over the irrigation works by the state. Further developments of the Marxist approach to the Indian past were to dominate the narrative of Indian history even much later, as we will see below.

history could be dated beyond a few thousand years. Until then the biblical narrative provided a short chronology of human history.

10 Yelle 2013, 3-70.

11 Majumdar 1960, xi.

12 Majumdar 1960, xi.

13 Seed 1952.

14 See also Fabian, ch. 13, this volume. 
While the Hindu texts were considered devoid of historical fact, the only respite scholars could draw was from Buddhist literary sources, especially the Pali chronicles of Sri Lanka. These texts gave them the additional satisfaction of relating the information from texts to the material evidence of monuments like stūpas, vihāras, and other extant buildings. Moreover, Western Indologists could corroborate the information they gained from Buddhist texts with the accounts of Chinese pilgrims like Faxian (early fifth century CE) and Xuanzang (seventh century CE).

The early nineteenth century was also the period of exploration and research. Central Asia was explored by Captain Alexander Burnes, Kabul by Charles Masson, the Punjab region by Jean-Baptiste Ventura and Claude Auguste Court, and Sarnath by Alexander Cunningham. This spurt of explorative energy led to the first collections of coins and other antiquities, mostly from Buddhist sites. Various geographical surveys by officials of the East India Company had brought to light a variety of material remains, most notably the inscribed stone edicts soon to be attributed to Aśoka, but also the copper plate inscriptions, architectural remains, and coins. James Prinsep deciphered two ancient scripts of India between 1834 and 1835. These scripts were named Brāhmī and Kharoșțīi. The decipherment enabled the identification of the Aśokan edicts, as well as the identification of the Kuṣānas, Indo-Greeks and many other ruling dynasties from their numismatic issues. ${ }^{15}$

Alexander Cunningham, often regarded as the father of Indian archaeology, found material remains to be reliable sources offering some glimpses of the past. His inclination is visible in the proposal he made to increase archaeological investigation instead of engaging in texts only. ${ }^{16}$ Pointing to the absence of any reference to Buddhism in the Brahmanical texts, he considered that separate research on Buddhist history was important. Cunningham had proposed establishing a centrally organized body that would introduce a systematic process of explorations and excavations of Buddhist sites. His endeavors resulted in the establishment of the Archaeological Survey of India (ASI) in 1861. Throughout his writings, he showed a special interest in what he called "the Buddhist period of India." For the study of the geography of the period, he used the paths followed by Alexander during his campaigns in the northwest and the travels of the Chinese pilgrim Xuanzang. ${ }^{17}$

Enthusiasts of history also relied on the identification of historical figures and places known from Graeco-Roman sources, one example being Alexander of Macedonia. ${ }^{18}$ For Indologists searching for historical facts, the classical Western accounts had better value as historical sources, because they had ascribable dates and accounts of a nonreligious nature. Alexander's campaigns appeared as the only undisputed historical point of reference, and his account of India as the only reliable

15 Dwivedi 2015, 210-211.

16 Cunningham 1848.

17 Cunningham 1871, 104.

18 Potts and Ray 2007. 
source of history. By the beginning of the twentieth century, the two historical phenomena that marked Indian civilization were the Buddha and Alexander. This was clearly visible in V. A. Smith's famous work from 1908, The Early History of India.

\section{II.2 Restoring Indian Past: Beginnings of Economic History Writing}

The turn of the twentieth century brought two revolutionary discoveries that changed the course of Indian history writing. One was the discovery of the Kautiliza Arthaśāstra (KA) in 1905; the other was the archaeological discovery of the Indus Valley Civilization of the Bronze Age in the 1920s. The latter pushed back the antiquity of India as a civilization to the third millennium BCE, while the $K A$ proved ancient Indians as capable of scientific and rational thought.

The $K A$, a political and economic manual dated to the Mauryan period, represented a model of a well-developed centralized state. ${ }^{19}$ The text was used to study the Mauryan fiscal economy, and demolished the long held assumption of an everapolitical India of social stagnation, lacking a sense of history, and ruled by Oriental despotism. ${ }^{20}$ The Indian political past was now considered on par with that of the European civilizations, and there were parallels to be drawn with the Greek and Roman political philosophies. The practice of drawing parallels was quite typical in early conventional interpretations of the $K A$ and must be seen as a reaction to the European superiority complex and obsession with the unique greatness of ancient Greece and Rome in the field of politics and economics. ${ }^{21}$ The traditional Indian political understanding could now be compared with the political theories of Machiavelli, Plato, Aristotle, and other Western political thinkers. ${ }^{22}$

These two findings influenced indigenous history writing in the early part of the twentieth century as well. Indian scholars set out to "restore to Indians their lost past, and instil in them a sense of pride in their own ancient heritage," and explicitly prove "that India had traditions, especially of government, no less than those of Britain, and therefore was capable of governing itself." 23 The newly discovered $K A$ was one of the important reasons that various works on economic history, with special reference to the fiscal economy, were being written between the 1930s and 1940s. The scholarship that was produced to restore the image of India's past has been named the nationalist school of history. They brought related topics into

19 See Dwivedi ch. 10.A, this volume. For an evaluation of the use of the text to study the monetary system of the Mauryan period, see Bhandare 2012.

20 Voigt 1966, 51, 65. For Oriental despotism, see below. See also Fabian, ch. 13; Morris, ch. 16, this volume.

21 Voigt 1966, 51.

22 Keith (1920) 2002, 452-453; Krishna Rao 1953.

23 Seshan 2007, 155-178. 
discussion such as agrarian structures, property ownership, urbanism, city planning, and long-distance trade. These will be discussed later in this chapter.

The early twentieth century also saw a participation of many Marxist scholars in the writing of Indian history. The earliest critique of the idea of the West along cultural, political, and evolutionary economic lines came from Marxist Orientalism. As the West represented modern commerce, world trade, territorial acquisition, and capitalist rationality, a contrast and opposition to this was drawn with Asia, especially India, in the narratives of the leftist Orientalists. Theodor Lessing's Europa und Asien (1915) was a work against Eurocentricism. He argued for the comparative study of the Chinese, Indian, Islamic, Jewish, and Persian civilizations, which presented rich and sophisticated "cultural wholes." ${ }^{24}$ Criticism of Eurocentric approaches also became favorable among Indian scholars.

It was mainly the Marxist criticism of Eurocentrism that attracted the Indian scholars to the idea of economic determinism in history writing. Marxist and neoMarxist approaches appeared in the 1940s, however they gained prominence only after independence. Two of the earliest proponents of Marxist methods of history writing were D. D. Kosambi and Mohammad Habib. Mohammad Habib took up the study of the medieval period, challenging the prevalent notion that the medieval Indian state was a theocratic one. D. D. Kosambi was the first to move the focus of history from political events and dynasties to the study of Indian society and economy. He was the first scholar to apply methods of structural functionalism, placing the religious texts in their temporal and social context. His contribution also lies in the bridging of historical archaeology and history, considered until then to be a mismatch. His methods focused on contextualizing sites and settlements in their surroundings in order to understand the continuities of traditions. He was also among the earliest scholars to have brought into use literary sources that had been disregarded earlier because of their religious content and lack of facts or empirical data. To a large extent, Kosambi's work marked a turning point in Indian historiography away from the positivist method that had been used by both imperialist and nationalist historians.

\section{II.3 From Economic to Cultural History and Other Criticisms}

Edward Said's Orientalism, published in 1978, fundamentally reshaped the historiography of Third World countries. It questioned the Western methods of writing the past, and in particular the concepts and theories produced in the colonial period. It also led to a certain decline in economic history writing in favor of cultural studies, marginalizing questions of the political economy of the state. Cengiz Kurlı noticed

24 For a detailed discussion, see Manjapra 2014, 175-179. 
the shift in Ottoman studies from economic to socio-cultural aspects. ${ }^{25}$ As historical agency had been recast as indigenous, the scope and questions of the studies are more focused on regional and local processes, moving away from the grand empirebased Eurocentric models.

In the Indian context, state-centric economic history was also regarded as obsolete by Tirthankar Roy in the 1990s. His criticism was directed above all against Marxist methods of economic history writing. The period between 1950 and 1990 had been a phase of socialist leaning, leading to economists seeing a great relevance in history. The collaboration of historians and economists was a marked phenomenon of this period. Yet economic history underwent a decline during the post-socialist period and the shift of India to a modern market economy. ${ }^{26}$ Works on the modern/ colonial economic history of India had placed the colonial state at the center. The state had also been an important focus of Marxist historiography. Not only did this model see empires as agents of economic change, but any absence of powerful political structures or states was regarded as correlating with rural, self-sustained, and closed economies, in all their negative senses. It was after the publication of two volumes of The Cambridge Economic History of India in 1982 that the relevance of state-centric economic history came to be questioned. One of the reviewers of the volumes accused the authors of being stuck in the methodologies of the 1960s and suggested that the economic history writing elsewhere had moved on. ${ }^{27}$ Since the discipline of economics abandoned the paradigm of political economy in the phase after economic liberalization, historians of a Marxist conviction and reformist economists had little to say to each other. Yet this does not mean that the state has become immaterial to the study of economic history. Rather, the state is seen to be important to any discourse of long-term economic change. Roy perceives the relationship between economics and history that created state-centric history both as a product of the political needs of the period and as a tool for inspiring public policy:

\footnotetext{
The belief in politically induced market failure served as a strong link between the past and the present in the Nehruvian era. Economists and historians both invested 'market failure' with foundational status in their respective analytical systems. Economists and historians agreed that markets and the open economy were instruments that needed to be restrained, if used at all. Historians thereby gave meaning to a regime that intervened heavily to restrain market forces and international relations ... Historiography, in other words, supported the political establishment. The ruling historiography, furthermore, was singularly compatible with the ruling economic sentiment that upheld an insular and state-dominated development strategy. ${ }^{28}$
}

The echoes of postcolonial narratives influenced the study of ancient history as well. Various authors raised questions about the ways history was written and the

25 Kirli 2014.

26 Roy 2004, 3238.

27 Perlin 1988.

28 Roy 2004, 3240. 
problems associated with the methods and theories within their fields. Postmodernism and postcolonialism brought about a loss of the sense of absoluteness of Western accounts of history. In an important essay on general ancient history writing, titled "The study of early India," B. D. Chattopadhyaya identified many problems of the colonial and West-centric approaches to history. ${ }^{29}$ He pointed to the disjuncture between precolonial modes of history writing and the ways Indology developed in the eighteenth century, and how this had affected the shaping of the cultural consciousness of India itself. The major premises that seemed to govern our historical thinking today were all rooted in the colonial past. Neither the itihāsa-purāna tradition, which is representative of the historical thought of early India, nor, for that matter, the Islamic distinction between a pre-Islamic barbaric past and the birth of a true history with the rise of Islam can explain how history is categorized and periodized in the present time. ${ }^{30}$ Although Chattopadhyaya stresses the difference of Indian sources and methods of historiography, he does not argue for a correct indigenous perspective vis-à-vis colonial ones. 'Eastern' and 'Western' ideological approaches were difficult to disentangle, and perhaps this is not required. While he acknowledges the limitations and hegemonic aspects of colonial historiography, he does not imply that only Indians should produce their own 'national' histories. In fact, he warns that in doing so there would be the great danger of inverting hegemonization, that is, reverse hegemonism. Reverse hegemonism is the assumption of a natural cultural and spiritual superiority of Indians. This, too, would be undesirable according to Chattopadhyaya.

Over the last decade, historiographical studies have very consciously placed scholarship and ideas in their historical contexts. These include discipline-reflexive or discipline-critical studies. One example is the collection of essays by Trautmann. ${ }^{31}$ These essays explore the encounters of Western rationalism and Indian philosophies. They illustrate how Western scholars struggled with the Indian concepts of time, history, chronology, and identities. Various essays position Western philologists and historians in their social, religious, and ideological background.

Another interesting work is that of Robert Yelle. ${ }^{32}$ Questioning the secular and rational nature of science, and of the historical disciplines in particular, he does not consider rationality and rationalism devoid of religion. Rather, what was commonly regarded as rationality represented the inheritance of one particular religious culture, Protestant Christianity. The study of colonial encounters helped to add some historical perspective to inherited ideas, which were neither rational, nor secular, nor universal, nor ineluctable. ${ }^{33}$ Demonstrating how the Indian past, literature, and

29 Chattopadhyaya 2003, 3-5.

30 Chattopadhyaya 2003, 4.

31 Trautmann 2009.

32 Yelle 2013.

33 Yelle 2013, $x$. 
religion were viewed by its outsiders, he shows the non-secular nature of Indology in British India. Indian religion, moreover, was confronted with comparable criticism as applied to Catholic and Jewish religions by Protestants in between the seventeenth and nineteenth centuries.

Another discipline-reflexive work is that of Adluri and Bagchee. ${ }^{34}$ Adluri and Bagchee question history as an enlightened, nonpolitical, and nonideological science. They explain how the claim that history was scientific and rational dominated the narratives about Europe's encounter with the Orient. Focusing on the discipline of Indology, and German Indology in particular, Adluri and Bagchee argue that these works were radically theological, though capturing the imagination of Indologists throughout the globe as being objective and scientific. One example for Adluri and Bagchee is the method of textual criticism. This method aimed to establish the original version of a text free of later corruptions. But this approach to Sanskrit texts was entirely inappropriate, being informed instead by neo-Protestant biblical studies and text exegesis, where the establishment of the true word of the Bible formed the primary intellectual and spiritual goal. ${ }^{35}$

\section{Topics and Questions in Indian Economic History}

The theories and frameworks of the history writing of early India draw heavily from the models and methods adopted from the study of history, but other disciplines, such as archaeology, anthropology, economics, sociology, philology and linguistics, philosophy, etc., were also influential. Although my discussion here focuses on economic history writing between $300 \mathrm{BCE}$ and $300 \mathrm{CE}$, it is difficult to separate issues related to this period from those of the centuries before and after. ${ }^{36}$ For example, the study of urban centers and processes of urbanization in ancient India needs to be contextualized within the concepts of first urbanization (the Bronze Age Indus Valley Civilization), second urbanization (sixth century BCE to fourth century CE), and another phase of urbanization with the coming of Islam (eight/nineth to eleventh/thirteenth century $\mathrm{CE}$ ). Moreover, centralization and feudalization of econo-

34 Adluri and Bagchee 2014.

35 Adluri and Bagchee trace the origin of textual criticism to Johann Salomo Semler (1725-1791). Whereas orthodoxy taught that the Bible and the dogma were absolute, Semler suggested that there were in fact different temporal and spatial layers. With this approach, the content of the books of the Bible were localized and temporalized. This was done in order to be able to free the Bible of its local and temporal components and to identify its true content for "the moral betterment of humanity" (Adluri and Bagchee 2014, 12-14).

36 Some works discussing the development of economic history writing about ancient India are: Morris and Stein 1961; Sharma and Jha 1974; Chakravarti 2001; Chattopadhyaya 2003, 217-232; Ray 2011; Basant 2012, 4-54. 
mies were discussed in the context of debates over state formation processes and the rise and fall of empires more generally. And finally, research on foreign contacts and their economic impact was informed by research on other historical periods and projected onto ancient times using various modern theoretical approaches.

It is important to draw attention to the problem of periodization in Indian history at this juncture. What demarcates a transition and the beginning of a new period is still baffling historians. ${ }^{37}$ The Indian past was presented to the world for the first time by James Mill in 1817. He distinguished three periods, Hindu, Muslim, and British. Over a period of time this came to be replaced by another scheme of periodization, ordering history into ancient, medieval, and modern periods. The new method indicated that the transition from one period to another was no longer related to political transformation alone, but to the socio-economic shifts that were brought about by them. Transformation was framed in terms of the economic, social, and political dynamics of the period, and processes of urbanization and ruralization were alligned with the rise and fall of empires. However, the underlying notion of transition remained the same as in Mill's scheme: the medieval period and the economic changes brought about by it were marked by the coming of Muslim rule, and the modern period began with rule of the British from the mid-eighteenth century onward.

The ancient period is further subdivided into protohistoric (Bronze Age or Indus Valley Civilization), early historic (sixth century BCE to fourth/sixth century CE), and early medieval (seventh to eleventh/thirteenth centuries). The period of $300 \mathrm{BCE}$ to $300 \mathrm{CE}$ thus falls into the middle of the early historic phase. Even though poorly defined, the term 'early historic' has been commonly accepted in academic writing. Yet R. S. Sharma was the first to point to the ambiguity of the term 'early' and the problems of definition arising from its use. ${ }^{38}$ To him the use of the terms 'early historical' and 'early medieval' in archaeological reports was an advancement over previous attempts of periodization; however, their precise meaning in terms of chronology, concept, and material culture remained unexplained. This problem was also raised by B. D. Chattopadhyaya in relation to archaeological sites. He criticized especially the sweeping use of 'early historic' across the subcontinent where particular characteristics of material culture occurred at different times. The lack of definition of what cultural assemblage qualified a period or stratum as being early historic made the terminology highly ambiguous. As a result, there is always the possibility of stretching the term far beyond the concerns and technicalities of archaeology. ${ }^{39}$

37 This can be seen in a recent publication that attempts to disentangle the problems of periodization and questions regarding defining transitions in course of South Asian history (Seshan and Kumbhojkar 2018).

38 Sharma 1987, 3.

39 Chattopadhyaya 2008, 12. 


\section{III.1 Studies in Agricultural Society and Urban Spaces}

The nineteenth- and early twentieth-century capitalist perspectives on global history put special emphasis on the urban. As mentioned above, British writing on Indian history above all had conceived of early Indian society as mainly rural, agrarian, and stagnant. This was conceptualized in Marx's Asiatic mode of production and was reiterated by V. A. Smith in 1908. While some scholars agreed to the model proposed, others found it difficult to accept. These views were challenged within two decades by Indian scholars, who were then termed 'Nationalist' historians.

One of the earliest economic histories dealing with issues of agriculture was the compilation of six lectures by Samaddar published in 1922. He relied heavily on Indic sources, the Vedas, śāstras and sūtras, the two epics (the Mahābhārata and the Rāmāyaṇa), the Buddhist jātakas, and especially the newly discovered $K A$. The revenue and agrarian systems in ancient northern India were the subject of two publications by U. N. Ghoshal just a few years later. ${ }^{40}$ These were closely followed by Gangopadhyaya, who extensively used the $K A$ to refute various notions of exploitative state machinery and heavy taxation as suggested in the model of the Asiatic mode of production and Oriental despotism. ${ }^{41} \mathrm{He}$ also used the dharmaśāstras to show the presence of private ownership of land. While private ownership of land is now generally accepted, the question of whether water management was a state enterprise or controlled by local communities is still unsettled.

Postindependence socio-economic history writing argued against the generalized views of Indian society as an essentially rural and stagnated economy. The dharmasūtras and dharmaśāstras were brought to bear on private landownership, and the Buddhist texts became important for showing commercial activities and centers, thus challenging the notion of a stagnant, self-sustained agrarian village economy. The sixth century BCE in northern India came to be described as a dynamic urban phase where and when urbanization was closely associated with socioreligious diversity, a flourishing economy, and the emergence of trade centers. ${ }^{42}$ To a large extent, economic history writing of India at that time focused on trade, centers of exchange, and the growth of towns and cities as a result of urbanization processes. Yet, even though scholarship from the mid-twentieth century started to show the subcontinent's urban potential, the hinterland, agrarian history, and rural landscape continued to be regarded as economically stagnant and immutable. The expansion of agriculture was seen as a sign of feudal tendencies concomitant with a decline in foreign trade. ${ }^{43}$ The phases of early historical urbanization, both the

40 Ghoshal (1929) 1972; 1930.

41 Gangopadhyaya 1932.

42 Sharma 1983a, 89-135; Wagle 1995; Thapar 1992, 70-115.

43 The fourth and fifth centuries CE are seen as the period of decline in the urban centers as a result of the end of the Indo-Roman trade. Named the 'early medieval period,' it has been studied as a phase of feudalism (Sharma 1983a; 1987; Sahu 2001). 
'second urbanization' of the sixth century and the 'secondary urbanization' of the post-Mauryan period, from the second century BCE onward, were determined with reference to increasing commercial trade and monetization. These indicators of a burgeoning economy, however, were studied mostly in the nonagrarian sector.

The expansion of agriculture is not only a topic of economic interest, but also related to social and political questions. Most scholars of ancient India associate the emergence of imperial states in the Ganga valley with its fertile alluvial plains. The development of uncultivated areas was regarded as a technique of territorial expansion in the process of state formation, while agricultural expansion was correlated with increasing social complexity. In Marxist narratives, it was understood especially in terms of development of social hierarchies and an exploitative class system (more precisely the varna). The varna system, commonly translated as and equated to a 'class system,' consists of four socio-ritual hereditary groups with specific economic and social functions as prescribed in the normative texts, especially the dharmaśāstras. Social formations were studied in the light of exploitative hierarchical relations in which most of the manual labor was in the hands of the lowest socio-ritual group, the śüdras (literally meaning 'small' or 'minute'). ${ }^{44}$ These were considered the servile class who were to serve the other three higher varnas (brāhmaṇa, kṣatriya, and vaișya). Agricultural laborers were possibly also śūdras.

Other scholars focused on the issues of productivity and did not engage in the debates about state formation. One example is the work of M. S. Randhawa. ${ }^{45}$ His survey of agriculture is more encyclopaedic, starting from prehistory and moving on to types of agricultural production, allied activities, and technological progress from the third century BCE onward. The period between the first century BCE and the third century CE, in particular, was a period of technical advancement that saw better water management and the development of new practices like sharecropping, commercial cropping, multicropping, etc. ${ }^{46}$

Irrigation was another well-discussed issue in economic history. One group of scholars emphasized the role of the central state in the building and managing of irrigation works. Agricultural revenue was the main source of income for the administrative machinery in charge of the maintenance of irrigation. ${ }^{47}$ Others suggested a more community-based management of irrigation works and related it to the patronage of Buddhist monasteries. Further, monastic landlordism in Sri Lanka and their exchange relation with the laity suggested similar tendencies in areas of Gujarat and Madhya Pradesh. The expansion of Buddhist networks is also associated with the introduction of rice cultivation in central India, which requires a more consist-

44 Some works that prominently argue about the class antagonism and social constitution of the peasant society are: Sharma 1983a; 1990; Thapar 1992.

45 Randhawa 1980.

46 Randhawa 1980. See also Gopal and Srivastava 2008.

47 Ghoshal 1930; Sharma 1983b; Chakravarti 2008. 
ent irrigation system. ${ }^{48}$ Instances of the donation of wells and water tanks from Mathura ${ }^{49}$ and Gandhāra, ${ }^{50}$ as well as the presence of tanks at Kashmir Smast, ${ }^{51}$ link the water management with ritual and monastic sites. In the context of southern India and Sri Lanka, recent studies have related ancient water tanks and reservoirs more closely to settlements and mortuary sites, although their association with agriculture is not denied. ${ }^{52}$ Sri Lanka, apart from tanks, had a method called the Tank Cascade system, which is based on recycling and reuse of water through a network of small to large tanks. ${ }^{53}$

\section{III.2 Definitions of Urban Space and Urbanization}

During the 1970s and 1980s, studies in early Indian urbanization became more rigorous. These studies echoed the debates over technological determinism, on the one hand, and the importance of socio-cultural factors, on the other, which had been at the center of intellectual concerns of Western scholars in the 1950s and 1960s. Within the Indian context, the two sides of the debate related urban development to either increased agricultural surplus achieved by the use of iron technology, ${ }^{54}$ or to socio-cultural and political aspects that affected the allocation of resources. ${ }^{55}$ Even though these differences are no longer very stark, history writing may still be cate-

48 Shaw and Sutcliffe 2003b; 2003a; Shaw 2007; Shaw et al. 2007.

49 Inscription nos. 84 and 149b in Lüders 1913.

50 Falk 2009.

51 Kashmir Smast is located on the southern slopes of the northern peripheral mountain chains of the Peshawar basin in modern Pakistan. The dates of the tanks are very tentative, see Khan 2006, 29-31; 2011, 96.

52 Bauer and Morrison 2008; Morrison 2009, 3-6.

53 Brohier 1934. See also Geekiyanage and Pushpakumara 2013.

54 Kosambi (1956) 2009; (1955) 2002; Sharma 1974. In R. S. Sharma's formulation, the state and urbanism originate together and owe their beginnings to the use of iron for advanced food production techniques, which created agricultural surplus. This surplus, in turn, maintained priests, administrators, professional soldiers, the capital consisting of the ruler's establishment, artisans, traders, etc. (Sharma 1983a, 16). Urbanization was studied through various perspectives such as the simultaneous emergence of urban centers, long-distance trade routes, state formation, and often monetization. Economic determinism was also used to explain ruralization of the economy, decline of urban centers, decentralization and fragmentation of the state, and their reflection in the economy through demonetization. These were the attributes ascribed to the beginning of feudalism in India, when the decline of Indo-Roman trade was considered a reason for the decline of urban centers and monetary economy.

55 A reference to the social complexity and criticism to the economic determinism was first visible in a work of Ghosh (1973), where he argued that economic aspects are to be seen as a social product. Other criticism came from Chakrabarti (1972a; 1972b; 1992), who pointed to the dangers to implanting the Western models of enquiry in the Indian context, and urged scholars to look at the sociopolitical uniqueness of the Indian context. 
gorised into two groups: those arguing for economic determinism, and those emphasizing socio-cultural and religious factors.

The definition of 'urban' has been another issue. The use of archaeological material to trace urbanization is not new. Gordon Childe identified various determinants of urbanization in historical contexts. ${ }^{56}$ The criteria included fortification; varied crafts; luxury items of precious and semiprecious stones; the presence of script and forms of writing; indications of towns and cities in long-distance overseas trade routes; and coinage, both imperial and local. After his study, many scholars tried to apply similar criteria to understand urbanization processes in the early historical period. In response to Childe, R. S. Sharma cautioned the students of history. ${ }^{57} \mathrm{He}$ criticized the practice of identifying a site as urban just on the basis of size and population, as to him it was "the quality of material life and the nature of occupation" that was to be emphasized. Neither a large population nor the size of a settlement itself automatically qualified a site as urban. However, to a large extent the markers of urbanization in India are nuanced adaptations of Childe's characteristics. The common features in material remains that are used as identifiers of an urban site are as follows: the presence of fortification and ramparts along with coins; ${ }^{58}$ increasing and common use of iron implements; ${ }^{59}$ text, exotic ceramics, coins, glass, and nonlocal raw materials; ${ }^{60}$ burnt brick structures, ring well, and other water storing facilities; ${ }^{61}$ and foreign influences in art. ${ }^{62}$ Additionally, an urban site is expected to have a differentiated and heterogeneous space, including distinct spaces for roads, artisanal areas, religious shrines, and other types of community spaces, along with residential buildings. ${ }^{63}$

Recently, archaeologists and anthropologists have started looking at urbanization as a wider process rather than merely as an event at a given archaeological site. D. K. Chakrabarti explored the aspects of connectivity and networks by looking not only at archaeological sites but also the connectivity, routes, and corridors between urban centers. ${ }^{64}$

R. Chakravarti approached urban contexts through economic hierarchies and social processes within a space. Descriptions of cities in texts help with the visualization of processes of wealth production, accumulation, and distribution. According to Chakravarti, "cities in the early historical period are not to be regarded as a loose

56 For the ten-point model to identifying urban sites, see Childe 1936.

57 Sharma 1987, 5.

58 Morrison 1997, 90.

59 Allchin 1995.

60 Lahiri 1992.

61 Sharma 1987; Lal 1986.

62 Chakravarti 2009, 139-140.

63 Chattopadhyaya 2003, 68.

64 Chakrabarti 2010. The trade routes mentioned by Chakrabarti, however, are based on possible routes in modern times, which could be questioned. 
agglomeration of traits (i.e., exchange and administrative centers) but should be viewed as a manifestation of a process which transformed the society from a more or less egalitarian phase into a sharply class differentiated one."65

\section{III.3 Connectivity, Trade, and Empire}

As a legacy both of colonial history writing and the Marxist theory of Oriental despotism, any trade that was prolific had conventionally been viewed as trade in luxury items controlled by imperial states. The emphasis had been on grand trade networks or trade routes, which proliferated during periods of imperial expansion and declined thereafter. ${ }^{66}$ Examples were the Mesopotamian trade of the Bronze Age, Indo-Roman trade during the early Common Era, Arab trade of the medieval period, and European trade of the modern period. The trading networks of India were considered to be sporadic phenomena. After a period of booming expansion and then cooling down, a phase of ruralization followed, with later wave of urbanization leading to the reemergence of new, different trade networks. Minimal or no continuity was seen between the Harappan (Bronze Age) trade and that of the early historic period. Equally, the economic changes in the early medieval period were regarded as rather unconnected to the trade networks of the early historic period.

For a long time, specialists of Indian economic history had worked with a model of economic determinism and a focus on state-centric economic history. In 1973, Colin Renfrew argued that ancient trade was integrally linked to early state formation processes. ${ }^{67}$ The theory of trade as an agent of change also gained currency in Indian historiography. Its impact is widely prevalent in Indian economic as well as cultural historiography. Trade was associated especially with the concept of 'secondary state formation' as well as the process of 'secondary urbanization' in the hinterland of the Indian subcontinent. ${ }^{68}$ Both processes were interconnected. In the theory of secondary urbanization, urban regions impart urban traits to regions with which they come into contact. The secondary state formation model suggests that a developed state machinery propells the political structure of other pre-state societies into state formation. In the Indian context, for example, the Mauryan Empire is seen as such a state. After the Mauryas, the majority of India, if not the entire subcontinent, is seen to have gone through secondary urbanization and secondary state formation.

Empires were ascribed not only the role of uniting geography, but also of homogenizing economic systems and bringing about cultural unity. The Mauryan Em-

65 Chakravarti 2007, 39.

66 For a review and critique of this historiographic trend, see Ray 2003, 12-15; 2011; Ray and Mishra 2018.

67 Renfrew 1975.

68 Seneviratne 1981; Chattopadhyaya 2003, 66-102; Basu Majumdar 2017. 
pire is generally thought to have filled this role by centralizing the state, and thus the fiscal regime. ${ }^{69}$ Any connection of the center with a less developed region brought urban as well as administrative change to this region. This role was also ascribed to the Kuṣāna rule. This understanding is also owed to a wider tradition of archaeological research that associated artifacts with people and changes in pottery styles with changes of polities. For example, the Ganga valley in the first millennium BCE was characterized first by the "ochre colored pottery ware people," who were replaced by the "painted gray ware people," replaced in turn by the "northern black polished ware people" associated with the Mauryan polity. ${ }^{70}$ The pattern is followed in the identification of pottery type and sculpture as the 'Sunga and Kuṣāna types.' Based on these pottery types ${ }^{71}$ and on the size of the bricks, specific cultural phases, and more precisely, political phases are identified, which can be problematic. ${ }^{72}$ The Indian south, too, has commonly been understood through the model of secondary state formation as a result of Tamil contacts with the Mauryan Empire bringing about a complex state system and urbanization. ${ }^{73}$

A departure from economic determinism and state-centric economic history can be seen in the works that focus on the regional and interregional processes. The grand theories and histories of empires and their kings often overlook regional power nodes and social functionaries such as merchants, small landowners, and religious agents. ${ }^{74} \mathrm{~A}$ greater focus on regional processes, instead, sees economic transformations or urbanization in relation to the "dynamics of political and social power and in the changing religious landscape." $75 \mathrm{~K}$. D. Morrison has recommended considering the important role of religious groups regulating the long-distance travels. An example of this approach is the archaeological research in the Tungabhadra valley. The survey and excavation were aimed to investigate non-elite sites from the prehistoric to the medieval periods, landscapes of settlement, roads, temples, and agricultural facilities. ${ }^{76}$

69 Thapar 2006. For criticism, see M. Smith 2005; Ray 2008b.

70 Sinopoli, Johansen, and Morrison 2009, 11.

71 In the case of the early-historical site of Sanghol in Punjab, Ray (2010) raised a similar issue. The pottery cultures like the painted grey ware (PGW) and the northern black polished ware (NBPW) are considered styles of pottery uniquely associated with specific cultural-ethnic groups. A common example is that of Śunga-Kușāna pottery comprising the bowl, lid, inkpot, etc., without looking at internal diversity. On the basis of this kind of undifferentiated evidence, wider hypotheses about uniform urban town planning and state formation (Mani 1987). "The centralized Kushan Empire is seen as providing a foundation for the proliferation of urban settlements.” (Ray 2010, 7). 72 The introduction of burnt bricks is considered a distinct feature of Kuṣāna's standardization. Burnt bricks are associated with the urban enclaves under their rule. Ray points at the problem of such ascription. At Mathura, where 14 mounds were excavated, evidence for baked bricks is definitely pre-Kuṣāna (Ray 2010, 8-9).

73 Champakalakshmi 1996.

74 M. Smith 2005, 836; Ray 2008b, 11.

75 Morrison 1997, 88.

76 Out of the 12 monographs relating to this site, Bauer (2015) deals with the study of the economic and political complexities as visible from the landscape of the region in the early historic period. 
In several publications, H. P. Ray has proposed the study of economic questions together with social developments, in particular the close linkages of monasteries and other religious institutions with trade and credit systems. ${ }^{77}$ The settlement of Arikamedu, $4 \mathrm{~km}$ from Puducherry, grew along with the development of regional coastal networks related to the growth of trade in fish, pepper, and paddy, rather than in association with any central political elite, or as a Roman colony. ${ }^{78}$ Maritime activity had long been studied through references to foreigners in literature and their involvement in trade in luxury goods. For a long time, these methods resulted in the assumption that trade was controlled by the state. Representation of India in the Alexander historiography was the entry point for many scholars for the study of ancient India. ${ }^{79}$ Here India appeared above all as a source of luxury products for export. Ray and others have shown, by contrast, that this trade was based on much wider networks of local trade, having developed independently and trafficking in subsistence items such as timber, cloth, metal, dried fish, salt, medicines, and ritual commodities. $^{80}$

\section{III.4 Indo-Roman Trade}

The study of Indo-Roman trade has a tradition of more than a century. It was part of the broader history of the Indian Ocean associated with the commercial activities dominated by Roman actors. The presence of smaller networks of connectivity in the Persian Gulf and the Red Sea have been commonly accepted by most scholars from the fifth and fourth century BCE onward. ${ }^{81}$ However, studies of such networks have been controversial and have revolved around questions of initiative and agency, types of sources, and the nature of engagement between India and the Roman Empire.

Trade relations between India and Egypt from the third century BCE onward had already been pointed out by R. K. Mookerji in 1912. He suggested that, with the start of Roman control over Egypt from the first century BCE onward, Indian trade relations extended to the Mediterranean. Warmington's work in 1928 made Roman trade with India a matter of debate by emphasizing the Roman initiative of this trade and the Roman dominance in the Indian Ocean. Most of his findings and propositions did not remain unchallenged, although they were echoed for years. Even his contemporary, archaeologist R. G. Collingwood, had questioned his as-

77 Ray 1986; 1994a; 1994b; 2003.

78 Ray 2006, 119; 2008a, 193.

79 For a discussion on the nature of this literature, see von Reden, ch. 10.B, this volume.

80 Ray 2003, 6, 82-125; Fuller et al. 2011; Seland 2014, 386.

81 Salles 1998, 58, 66; Cobb 2018, 42. 
sumptions on navigation techniques and Graeco-Roman claims to the discovery of the monsoon winds. ${ }^{82}$

The dominance of Roman activity in the Indian Ocean was established by various finds of Mediterranean pottery at Indian sites, like Roman amphorae, terra sigillata, and what came to be called rouletted ware. After excavation of the port site of Arikamedu in 1945, Mortimer Wheeler concluded that the site was an emporion and was a merchant colony of the empire. ${ }^{83}$

In the 1980s and 1990s the dominant role of Romans in the maritime activity of the Indian Ocean was severely challenged. V. Begley's study of pottery from Arikamedu clearly contradicted the idea of Roman emporia in the Indian subcontinent. ${ }^{84}$ During this time, H. P. Ray provided a compelling new model and method of study in her monograph Winds of Change. ${ }^{85}$ She rooted maritime activity beyond trade within the religious and social context of Buddhism and Hinduism. Her subsequent works also placed maritime activity in the local cultural and religious milieu, as well as advocating for a connectivity of South Asia, Africa, and Southeast Asia older than Indo-Mediterranean connections. ${ }^{86}$ Her work has been influential for many other scholars since then.

Apart from the matters of origins and agency, the questions of what was traded and who benefited from Indo-Roman trade became an issue of discussion. The scholarship about who benefited economically from the trade may be grouped into four positions. ${ }^{87}$ The view with the longest pedigree is that the balance of trade was unfavorable for Rome, but favored India. There was an enormous inflow of gold and silver coins as attested by both Tamil sources and a famous statement by the Roman author Pliny the Elder. Another view states just the opposite: that the trade favored the Mediterranean, Egypt, and West Asia, while the outflow of coin was not a major factor for the Roman economy. Yet another view emphasizes that the concept of a balance of trade was rather alien to ancient states and could not be estimated without detailed statistics. A final point of view questions arguments about balances of trade altogether, as the trade was based simply on the demand of com-

82 Collingwood 1930; see also Evers 2017 for a brief survey of early research on Indo-Roman trade. 83 Wheeler, Ghosh, and Deva 1946; Wheeler 1954. The glorification of the Roman Empire was also glorification of the British Empire, as to a great extent the hegemonic ideas of the British Empire were validated by the claims of them as the sole inheritors of the Roman imperial mantel. The representation of the Roman dominance on their contemporaries was used to validate the British domination over others in modern time. Recent works demonstrate how the echoes of Roman imperialism were used by the British imperialists to justify their imperium. The Victorian and Edwardian traditions also had an influence on the archaeological practices even in the twentieth century. Study of Roman monuments and artifacts helped to draw the discipline of archaeology into the sphere of imperial discourses (Hingley 2000, 1-16; Ray 2008a, 187-217; Parchami 2015).

84 Begley 1983.

85 Ray 1994b.

86 Apart from various articles, two important monographs relating to this topic are Ray 2003; 2015.

87 Cobb 2018, 272-286 for further literature on these positions. 
modities from the Roman Empire to India and vice versa. Cobb suggests that silver and gold, especially in coined form, are unlikely to have been the main commodities of trade, since other commodities filling the ships, such as wine, oil, pottery, metal ore, glassware, wheat, barley, slaves, etc., had their own demand. They should not be regarded as ballast, or secondary to silver and gold coins, but as forming the greater portion of the ships' loads in total value. ${ }^{88}$

There are further arguments for dropping the labels 'Indo-Roman' or 'RomanIndian trade' for the commercial relation between the Mediterranean and South India. ${ }^{89}$ Thus Gurukkal has pointed to the fact that merchants from Roman Egypt traded with local merchants on the southwestern Indian coasts, which does not imply that trade was between two states. He points particularly to the (perhaps debatable) fact that South India was a pre-state society with little potential for stateorganized trade. Furthermore, he questions whether all transactions can be called trade. Trade and markets are neoclassical concepts, and there were very different forms of exchange contributing to the movement of goods between the Indian Ocean and the Red Sea. R. Chakravarti, while strongly supporting Gurukkal's views of dropping the labels, points out that the Roman commercial presence in India had no significant effect on local political and economic development, which should rather be sought in local dynamics. ${ }^{90}$

\section{III.5 Connectivity, Ports, and Hinterland}

The importance of maritime connections between South Asia, Indochina, and Southeast Asia, and their relationship to the wider question of commercial hinterlands of the Indian Ocean trade has often been emphasized by scholars. Even one of the earliest works on maritime connectivity explored Indian exchange relations with Southeast Asia. ${ }^{91}$ Recent works have also emphasized the need to look for communities and small participants to understand the seafaring traditions. ${ }^{92}$ The role of the Bay of Bengal in maritime relations has been studied by looking at the movement of ideas, people, and material objects. ${ }^{93}$ Salles explains the nature of the port

88 Cobb 2018, 272-286.

89 Gurukkal 2016.

90 Chakravarti 2017, 333-338; Chakravarti 2007 also emphasized the study of regional centers of exchange, such as puțabhedana, maṇapikas, and pențha, which offer glimpses into the complexity of market places.

91 Mookerji 1912. For more recent works on South and Southeast Asian maritime relations, see the edited volumes by Kulke, Kesavapany, and Sakhuja 2009; Manguin, Mani, and Wade 2011.

92 Ray 1994b; Ray and Salles 1996; Ray 2003; Ray and Mishra 2018.

93 With reference to the movement from the east coast of materials including (but not limited to) glass, flora and fauna, pottery, minerals, and metal, see Kanungo 2004; Fuller et al. 2011; Murphy et al. 2018; Tripati 2011; Tripati, Patnaik, and Pradhan 2017; Ray and Mishra 2018. 
sites on the Bengal coast as local distribution centers. He points out that the ports could be considered as centers in the sense of a Polaniyan 'port of trade,' which were centers of distribution in a frontier zone. ${ }^{94}$

The study of relationships between ports and inlands has been a dynamic field of research in the historiography of connectivity. Begley repositioned the site of Arikamedu from a standalone Roman emporion to a series of interrelated settlements along the Gingee River. Port sites like Korkai and Kaveripattinam have also been studied with respect to their connections with inland regions. ${ }^{95}$

Deloche has emphasized the importance of the fluvial connectivity of the ports, more so since the famous ports of ancient period, often understood as coastal ports, are rather at the mouth of riverine estuaries. ${ }^{96}$ The need for connectivity with inland regions is also one of the important concerns of the early ports. An example is that of the Palghat (Palakkad) Gap, which allows for a land route between two chains of hills (the Nilgiris and Anaimallai), connecting the west of the hills with the east. The Palghat Gap allows an easy passage to the east where three minor rivers drain into the Kaveri River, allowing the channelling of traffic across India from the Arabian Sea to the eastern coast of India. ${ }^{97}$ The geographic location of the corridor also reduces the need for navigation around the southern tip of the subcontinent through the shallow waters of the Gulf of Mannar, and even around the island of Sri Lanka (see ch. 3, map 1).

Further decentralization of ports and coastal locations has been recently advocated. ${ }^{98}$ Thus, the use of the term 'hinterland' to define the interior regions of southern India and the use of 'foreland' for the ports has been criticized. The commodities that passed into different regions through the Indian Ocean ports were not the produce of the littoral region. The most important commodities such as spices, timber, textile, gemstones, and metal were instead obtained from the upland and interior regions in the peninsula. The inhabitants of the inner regions had their own sociopolitical and historical contexts as well as complexities, which shaped their engagement with the merchants. The presence of traditional exchange networks and the participation of the inner land in them has been advocated by bringing the presence of nonlocal items excavated from inland sites into focus. The mortuary remains found in excavations have shown increasingly differentiated practices of production and consumption, as well as settlement configurations. ${ }^{99}$

94 Salles 2004 questions the attribution of Wari-Bateshwar (in Bangladesh) as an administrative center, economic hub, and entrepôt. Salles's criticism of the site has the potential of challenging the centralization of coastal ports in the narrative of undifferentiated long-distance exchange relations. For the concept of the port-of-trade as frontier zone space of exchange, see Curtin 1984; von Reden and Speidel, ch. 17, this volume.

95 Begley 1983.

96 Deloche 1983; 1994, 5-128.

97 Deloche 2010.

98 Bauer 2016.

99 Bauer 2016. 


\section{III.6 Merchants, Monks, and Voyagers}

While most work has concentrated on trade routes and trade connections, some important work has brought the human aspect of the movements into focus. Chandra raised the question of who was moving. ${ }^{100}$ Sea voyages and long-distance trade were conducted by caravans under the leadership of the sārthavāha. Based on the śāstras, scholars have identified the vaiśya varna (one of the four socio-ritual classes) as the merchants of the society. Their participation in the movement and trading activities, however, was not based on individual initiative, but they were organized, or organized themselves, as groups. There were various types of 'guilds' (śrenis), professional communities that have been discussed in detail by K. K. Thaplyal. ${ }^{101}$ Guilds as forms of social organization in early India were first studied by the German Indologist R. Fick, who dealt mainly with social or caste relationships prevalent in early northeastern India based on the Buddhist jātakas. ${ }^{102}$

The relation between Buddhism and urbanism has been an issue of discussion since the 1800s. However, the role of monks and monasteries as networks of exchange has been emphatically emphasized in more recent works. Kosambi had noticed the importance of Buddhist monasteries as centers of wealth and recognized their influence beyond religious matters. ${ }^{103}$ However, Ray developed the thesis of Buddhist patronage of long-distance merchants. ${ }^{104}$ The networks of connectivity and mobility facilitated through monasteries in connection with the traditional northern and southern routes, Uttarāpatha and Dakșin̄āpatha, have also been studied. ${ }^{105}$

People did not move just for reasons of trade, and trade may have been only one aspect of people's journeys. The movement of slaves between India and the Mediterranean is one example of such movements. ${ }^{106}$ Other types of people on the move were pilgrims. Ray suggests the possibility of Kanheri being a destination with pilgrim traffic because of its location on the trans-oceanic and overland long-distance routes. ${ }^{107}$ Sanchi is also suggested to have been a pilgrim site where pilgrims made donations. ${ }^{108}$ Overseas pilgrimage to the island of Socotra, usually regarded as stopover for traders in the Indian Ocean, might be indicated by the finds of lamps, frankincense, religious engravings, and small water tanks for ritual purposes. ${ }^{109}$ The religious importance of the island in later periods might also raise the

100 Chandra 1953; 1977.

101 Thaplyal 1996.

102 Originally published as Die Sociale Gliederung im Nordöstlichen Indien zu Buddhas Zeit in 1897, the work was translated by S. K. Maitra in 1920. See Fick (1920) 1987.

103 Kosambi (1955) 2002, 450-475.

104 Ray 1986; 1994a; 1994b.

105 Neelis 2011.

106 Cobb 2018, 195-196, 231; Hain forthcoming.

107 Ray 1994a.

108 Basant 2012, 191.

109 Kulshreshtha 2018. 
question of whether or not religious ritual was just a subsidiary activity of the earlier travelers who left their graffiti there. ${ }^{110}$ Wink argued that Socotra or Suquṭās was perhaps derived from the Sanskrit Dvippa Sukhatara, 'blessed isle,' and that this, too, might have had some significance as a pilgrim site. ${ }^{111}$

\section{Conclusion}

This chapter has focused on various issues and questions of historiography that developed over the course of time. One has to be careful not to treat different research agendas as successive stages in history writing. Many methods and theories have been contemporaneous, and similar research interests were spurred by different theoretical aims or preconceptions. This concerns the purpose of history writing in and about India as much as changes in the perceptions of sources, narratives of trade and urbanization, and regional approaches to economic history writing. My aim has not been to discard the chronological aspect of scholarship. Many issues in the economic, political, and intellectual historiography of early historic India have been abandoned, while others are recurring, and various questions are raised again and again. Also, decline of one dominant theory does not mean an end of its allied approaches. The end of colonialism did not mean the end of its methods and questions. Marxist views on the history of social struggle and centralized economic processes have not receded into the background even after its diminishment on a global platform. And today, even as we move away from state-centric economic history toward more holistic socio-cultural approaches, the practice of economic history writing continues.

\section{References}

Adluri, V., and J. Bagchee. 2014. The nay science: A history of German Indology. Oxford: Oxford University Press.

Basant, P. K. 2012. The city and the country in early India: A study of Malwa. New Delhi: Primus.

Basu Majumdar, S. 2017. "State formation and religious processes in the north-south corridor of Chhattisgarh (from first century BC to eighth century AD)." Studies in People's History 4.2, 119-129.

Bauer, A. M. 2015. Before Vijayanagara: Prehistoric landscapes and politics in the Tungabhadra basin. New Delhi: Manohar.

-. 2016. "Provincializing the littoral in Indian Ocean heritage: Coastal connections and interior contexts of the southern Deccan." In H. P. Ray (ed.), Bridging the gulf: Maritime cultural heritage of the western Indian Ocean, 101-119. New Delhi: Manohar.

110 For a discussion on inscriptions at Socotra, see Dwivedi, ch. 10.A, this volume.

111 Wink 1991, 45. 
Bauer, A. M., and K. D. Morrison. 2008. "Water management and reservoirs in southern India and Sri Lanka.” In H. Selin (ed.), Encyclopedia of the history of science, technology, and medicine in non-Western cultures. 2nd ed. 2207-2214. Berlin: Springer.

Begley, V. 1983. “Arikamedu reconsidered.” American Journal of Archaeology 87.4, 461-481.

Bhandare, S. 2012. “From Kauțilya to Kosambi and beyond: The quest for a 'Mauryan/Aśokan' coinage.” In P. Olivelle, J. Leoshko, and H. P. Ray (eds.), Reimagining Aśoka: Memory and history, 93-128. New Delhi: Oxford University Press.

Brohier, R. L. 1934. Ancient irrigation works in Ceylon. 3 parts. Colombo: Government Publications Bureau.

Chakrabarti, D. K. 1972a. "Concept of urban revolution and the Indian context." Puratattva 6, 27-31.

-. 1972b. "Beginning of iron and social change in India." India Studies: Past and Present 14, 329-338.

-. 1992. The early use of iron in India. Delhi: Oxford University Press.

-. 2010. India: An archaeological history: Palaeolithic beginnings to early historic foundations. New Delhi: Oxford University Press.

Chakravarti, R. 2001. “Introduction.” In R. Chakravarti (ed.), Trade in early India, 1-101. New Delhi: Oxford University Press.

-. 2007. Trade and traders in early Indian society. New Delhi: Manohar.

-. 2008. "Agricultural technology in early medieval India (c. AD 500-1300)." Medieval History Journal 11.2, 229-258.

-. 2009. "Relationship and interactions in the economic sphere." In B. D. Chattopadhyaya (ed.), History of science, philosophy and culture in Indian civilization. Vol. 2.5, 129-156. Delhi: Pearson Longman.

-. 2017. "Examining the hinterland and foreland of the port of Muziris in the wider perspective of the subcontinent's long-distance networks." In K. S. Mathew (ed.), Imperial Rome, Indian Ocean regions and Muziris: New perspectives on maritime trade, 307-338. London: Routledge.

Champakalakshmi, R. 1996. Trade, ideology and urbanization: South India 300 BC to AD 1300. Delhi: Oxford University Press.

Chandra, M. 1953. Sārthavāha. Patna: Rashtrabhasha Parishad.

-. 1977. Trade and trade routes in ancient India. New Delhi: Abhinav.

Chattopadhyaya, B. D. 2003. Studying early India: Archaeology, texts, and historical issues. New Delhi: Permanent Black.

-. 2008. "Early historical in Indian archaeology: Some definitional problems." In G. Sengupta and S. Chakraborty (eds.), Archaeology of early historic South Asia, 3-14. New Delhi: Pragati.

Childe, V. G. 1936. Man makes himself. London: Watts and Co.

Cobb, M. A. 2018. Rome and the Indian Ocean trade from Augustus to the early third century CE. Leiden: Brill.

Collingwood, R. G. 1930. "Review of: E. H. Warmington, The commerce between the Roman Empire and India." Antiquity 4.15, 384.

Cunningham, A. 1848. "Proposed archaeological investigation." Journal of Asiatic Society of Bengal 17, 535-536.

-. 1871. The ancient geography of India. London: Trübner and Co.

Curtin, P. D. 1984. Cross-cultural trade in world history. Cambridge: Cambridge University Press.

Deloche, J. 1983. "Geographical considerations in the localisation of ancient sea-ports of India." Indian Economic and Social History Review 20.4, 439-448.

-. 1994. Transport and communications in India prior to steam locomotion. Vol. 2, Water transport. J. Walker (trans.). Delhi: Oxford University Press.

-. 2010. "Roman trade routes in South India: Geographical and technical considerations (c. 1st cent. BC-5th cent. AD)." Proceedings of Indian National Science Academy 45.1, 33-46. 
Dwivedi, M. 2015. "Colonial imagination and identity attribution: Numismatic cues for defining space.” In H. P. Ray (ed.), Negotiating cultural identity: Landscapes in early medieval South Asian history, 206-238. New Delhi: Routledge.

Evers, K. G. 2017. Worlds apart trading together: The organisation of long-distance trade between Rome and India in antiquity. Oxford: Archaeopress.

Falk, H. 2009. "The pious donation of wells in Gandhara." In G. J. R. Mevissen and A. Banerji (eds.), Prajñādhara: Essays on Asian art, history, epigraphy and culture in honour of Gouriswar Bhattacharya, 23-36. New Delhi: Kaveri.

Fick, R. (1897) 1920. The social organization in north-east India in the Buddha's time. S. K. Maitra (trans.). Calcutta: University of Calcutta.

Fuller, D. Q., N. Boivin, R. Allaby, and T. Hoogervorst. 2011. "Across the Indian Ocean: The prehistoric movement of plants and animals." Antiquity 85, 544-558.

Gangopadhyay, R. 1932. Some material for the study of agriculture and agriculturists in ancient India. Serampore: N. C. Mukherjee and Co.

Geekiyanage, N., and D. K. N. G. Pushpakumara. 2013. "Ecology of ancient tank cascade systems in island Sri Lanka." Journal of Marine and Island Cultures 2.2, 93-101.

Ghosh, A. 1973. City in early historical India. Simla: Indian Institute of Advanced Study.

Ghoshal, U. N. 1930. The agrarian system in ancient India. Calcutta: University of Calcutta.

-. (1929) 1972. Contributions to the history of the Hindu revenue system. 2nd ed. Calcutta: Saraswat Library.

Gopal, L., and V. C. Srivastava, eds. 2008. History of Science, Philosophy and Culture in Indian Civilization. Vol. 5.1, History of agriculture in India (up to c. 1200 AD). New Delhi: Centre for Studies in Civilizations.

Gurukkal, R. 2016. Rethinking classical Indo-Roman trade: Political economy of Eastern Mediterranean exchange relations. New Delhi: Oxford University Press.

Habib, I. 2009. "Economics and the historians." Social Scientist 37.5/6, 3-20.

Hain, K. Forthcoming. "The prestige markers: Mediterranean slave women in India." Slavery and Abolition.

Hingley, R. 2000. Roman officers and English gentlemen: The imperial origins of Roman archaeology. London: Routledge.

Kanungo, A. K. 2004. "Glass beads in ancient India and furnace-wound beads at Purdalpur: An ethnoarchaeological approach." Asian Perspectives 43.1, 123-150.

Keith, A. B. (1928) 2002. The development and history of Sanskrit literature. Delhi: Sanjay Prakashan.

Khan, N. M. 2006. Treasures from Kashmir Smast: The earliest Śaiva monastic establishment. Peshawar: University of Peshawar Department of Archaeology.

-. 2011. "Hydrological setup at Kashmir Smast: Exploration and excavation at the Kashmir Smast field campaign 2006/2007: A preliminary report." Gandhāran Studies 5, 89-114.

Kırl, C. 2014. "From economic history to cultural history in Ottoman studies." International Journal of Middle East Studies 46.2, 376-378.

Kosambi, D. D. (1955) 2002. Combined methods in Indology and other writings. B. Chattopadhyaya (ed.). New Delhi: Oxford University Press.

-. (1956) 2009. An introduction to the study of Indian history. 2nd ed. Delhi: Popular Prakashan.

Krishna Rao, M. V. 1953. Studies in Kautilya. Mysore: H. Venkataramiah.

Kulke, H., K. Kesavapany, and V. Sakhuja, eds. 2009. Nagapattinam to Suvarnadwipa: Reflections on the Chola naval expeditions to Southeast Asia. Singapore: Institute of Southeast Asian Studies.

Kulshreshtha, S. 2018. "Practices of faith: Coastal shrines on the rim of the western Indian Ocean." Paper presented at Knowledge Traditions of the Indian Ocean World, Ashmolean Museum, Oxford, 29-30 November 2018. 
Lahiri, N. 1992. The archaeology of Indian trade routes up to c. 200 BC: Resource use, resource access and lines of communication. Delhi: Oxford University Press.

Lal, M. 1986. "Iron tools, forest clearance and urbanisation in the Gangetic Plains." Man and Environment 10, 83-90.

Lüders, H. 1913. "A list of Brahmi inscriptions from the earliest times to about AD 400 with the exception of those of Asoka." Appendix to Epigraphia Indica 10.

Majumdar, R. C. 1960. The classical accounts of India. Calcutta: Firma K. L. Mukhopadhyay.

Manguin, P.-Y., A. Mani, and G. Wade, eds. 2011. Early interactions between South and Southeast Asia: Reflections on cross-cultural exchange. New Delhi: Manohar.

Mani, B. R. 1987. The Kushan civilization: Studies in urban development and material culture. Delhi: B. R. Publishing.

Manjapra, K. 2014. Age of entanglement: German and Indian intellectuals across empire. Cambridge, MA: Harvard University Press.

Mookerji, R. 1912. Indian shipping: A history of the sea-borne trade and maritime activity of the Indians from the earliest times. Bombay: Longmans, Green and Co.

Morris, M. D., and B. Stein. 1961. “The economic history of India: A bibliographic essay.” Journal of Economic History 21.2, 179-207.

Morrison, K. D. 1997. "Commerce and culture in South Asia: Perspectives from archaeology and history." Annual Review of Anthropology 26, 87-108.

-. 2009. Daroji valley: Landscape history, place and the making of dryland reservoir system. New Delhi: Manohar.

Murphy, C., A. Weisskopf, W. Bohingamuwa, G. Adikari, N. Perera, J. Blinkhorn, M. Horton, D. Q. Fuller, and N. Boivin. 2018. "Early agriculture in Sri Lanka: New archaeobotanical analyses and radiocarbon dates from the early historic sites of Kirinda and Kantharodai (Kandarodai)." Archaeological Research in Asia 16, 88-102.

Neelis, J. 2011. Early Buddhist transmission and trade networks: Mobility and exchange within and beyond the northwestern borderlands of South Asia. Leiden: Brill.

Parchami, A. 2015. "The echoes of Rome in British and American hegemonic ideology." In K. Nicolaïdis, B. Sèbe, and G. Maas (eds.), Echoes of empire: Memory, identity and colonial legacies, 105-122. London: I. B. Tauris.

Perlin, F. 1988. "Disarticulation of the world: Writing India's economic history: A review article." Comparative Studies in Society and History 30.2, 379-387.

Randhawa, M. S. 1980. A history of agriculture in India. Vol. 1, Beginning to 12th century. New Delhi: Indian Council of Agricultural Research.

Ray, H. P. 1986. Monastery and guild: Commerce under the Sātavāhanas. Delhi: Oxford University Press.

-. 1994a. "Kanheri: The archaeology of an early Buddhist pilgrimage centre in western India." World Archaeology 26.1, 35-46.

-. 1994b. The winds of change: Buddhism and the maritime links of early South Asia. Delhi: Oxford University Press.

-. 2003. The archaeology of seafaring in ancient South Asia. Cambridge: Cambridge University Press.

-. 2006. "Inscribed pots, emerging identities: The social milieu of trade." In P. Olivelle (ed.), Between the empires: Society in India 300 BCE to 400 CE, 113-144. Oxford: Oxford University Press.

-. 2008a. Colonial archaeology in South Asia: The legacy of Sir Mortimer Wheeler. New Delhi: Oxford University Press.

-. 2008b. "Interpreting the Mauryan Empire: Centralized state or multiple centers of control." In G. Parker and C. M. Sinopoli (eds.), Ancient India in its wider world, 13-51. Ann Arbor, MI: University of Michigan Press. 
-. 2010. "Introduction." In H. P. Ray (ed.), Sanghol and the archaeology of Punjab, 1-19. New Delhi: Aryan Books International.

-. 2011. "Writings on the maritime history of ancient India." In S. Bhattacharya (ed.), Approaches to history: Essays in Indian historiography, 27-54. Delhi: Primus.

-. 2015. Beyond trade: Cultural roots of India's ocean. New Delhi: Aryan Books International.

Ray, H. P., and S. Mishra. 2018. "Introduction." In Bibliography on Sailing to Suvarnabhumi. AIC-RIS. http://ris.org.in/aic/bibliography.

Ray, H. P., and J.-F. Salles, eds. 1996. Tradition and archaeology: Early maritime contacts in the Indian Ocean: Proceedings of the international seminar Techno-Archaeological Perspectives of Seafaring in the Indian Ocean 4th cent. BC-15th cent. AD. New Delhi, February 28-March 4, 1994. New Delhi: Manohar.

Renfrew, C. 1975. "Trade as action at a distance: Questions of integration and communication.” In J. A. Sabloff and C. C. Lamberg-Karlovsky (eds.), Ancient civilization and trade, 3-59. Albuquerque, NM: University of New Mexico Press.

Rocher, R. 1983. Orientalism, poetry, and the millennium: The checkered life of Nathaniel Brassey Halhed, 1751-1830. Delhi: Motilal Banarsidass.

-. 1994. "British Orientalism in the eighteenth century: The dialectics of knowledge and government." In C. A. Breckenridge and P. van der Veer (eds.), Orientalism and the postcolonial predicament: Perspective on South Asia, 215-249. Philadelphia, PA: University of Pennsylvania.

Roy, T. 2004. "Economic history: An endangered discipline." Economic and Political Weekly 39.29, 3238-3243.

Sahu, B. P. 2001. "Brahmanical ideology, regional identities and the construction of early India." Social Scientist 29.7/8, 3-18.

Said, E. W. 1978. Orientalism. New York: Pantheon.

Salles, J.-F. 2004. "Archaeology and history of Bangladesh: Recent perspectives." In H. P. Ray and C. M. Sinopoli (eds.), Archaeology as history in early South Asia, 185-218. New Delhi: Aryan Books International.

Samaddar, J. N. 1922. Lectures on economic condition of ancient India. Calcutta: University of Calcutta.

Seed, G. 1952. "Lord William Bentinck and the reform of education." Journal of the Royal Asiatic Society 84.1/2, 66-77.

Seland, E. H. 2014. "Archaeology of trade in the western Indian Ocean, 300 BC-AD 700." Journal of Archaeological Research 22.4, 367-402.

Seneviratne, S. 1981. "Kalinga and Andhra: The process of secondary state formation in early India." In H. J. M. Claessen and P. Skalnik (eds.), The study of the state, 317-338. The Hague: Mouton.

Seshan, R. 2007. "Writing the nation in India: Communalism and historiography." In S. Berger (ed.), Writing the nation: A global perspective, 155-178. London: Palgrave Macmillan.

Seshan, R., and S. Kumbhojkar, eds. 2018. Re-searching transitions in Indian history. London: Routledge.

Sharma, R. S. 1974. "Iron and urbanization in the Ganga basin." Indian Historical Review 1, 93-103.

-. 1983a. Material culture and social formations in ancient India. Madras: Macmillan India.

-. 1983b. Perspectives in social and economic history of early India. New Delhi: Munshiram Manoharlal.

-. 1987. Urban decay in India, c. 300-c. 1000. Delhi: Munshiram Manoharlal.

-. 1990. Súdras in ancient India: A social history of the lower order down to circa AD 600. 3rd ed. Dehli: Motilal Banarsidass.

Sharma, R. S., and D. N. Jha. 1974. "The economic history of India up to AD 1200: Trends and prospects." Journal of the Economic and Social History of the Orient 17.1, 40-80. 
Shaw, J. 2007. Buddhist landscapes in central India: Sanchi Hill and archaeologies of religious and social change, $c$. third century $B C$ to fifth century $A D$. London: British Association for South Asian Studies.

Shaw, J., and J. V. Sutcliffe. 2003a. "Ancient dams, settlement archaeology and Buddhist propagation in central India: The hydrological background." Hydrological Sciences Journal 48.2, 277-291.

-. 2003b. "Water management, patronage networks and religious change: New evidence from the Sanchi dam complex and counterparts in Gujarat and Sri Lanka." South Asian Studies 19.1, 73-104.

Shaw, J., J. V. Sutcliffe, L. Lloyd-Smith, J.-L. Schwenninger, M. S. Chauhan, O. P. Misra, and E. Harvey. 2007. "Ancient irrigation and Buddhist history in central India: Optically stimulated luminescence dates and pollen sequences from the Sanchi dams." Asian Perspectives 46.1, 166-201.

Sinopoli, C. M., P. Johansen, and K. D. Morrison. 2009. "Changing cultural landscapes of the Tungabhadra valley, South India." In S. E. Falconer and C. L. Redman (eds.), Polities and power: Archaeological perspectives on the landscapes of early states, 11-41. Tucson, AZ: University of Arizona Press.

Smith, M. 2005. "Networks, territories, and the cartography of ancient states." Annals of the Association of American Geographers 95.4, 832-849.

Smith, V. A. 1908. The early history of India. 2nd ed. Oxford: Clarendon.

Thapar, R. 1992. From lineage to state: Social formations in the mid-first millennium $B C$ in the Ganga valley. 2nd ed. Delhi: Oxford University Press.

-. 2006. "The Mauryan Empire in early India." Historical Research 79.205, 287-305.

Thaplyal, K. K. 1996. Guilds in ancient India: A study of guild organization in northern India and western Deccan from circa $600 B C$ to circa 600 AD. Delhi: New Age International.

Trautmann, T. R. 2009. The clash of chronologies: Ancient India in the modern world. Delhi: Yoda Press.

Trautmann, T. R., and C. M. Sinopoli. 2002. "In the beginning was the word: Excavating the relations between history and archaeology in South Asia." Journal of the Economic and Social History of the Orient 45.4, 492-523.

Tripati, S. 2011. "Ancient maritime trade of the eastern Indian littoral." Current Science 100.7, 1076-1086.

Tripati, S., S. K. Patnaik, and G. C. Pradhan. 2017. "Maritime trade contacts of Odisha, east coast of India, with the Roman world: An appraisal." In K. S. Mathew (ed.), Imperial Rome, Indian Ocean regions and Muziris: New perspectives on maritime trade, 215-230. London: Routledge.

Van Hal, T. 2016. "Protestant pioneers in Sanskrit studies in the early 18th century: An overlooked chapter in South Indian missionary linguistics." Historiographia Linguistica 43.1/2, 99-144.

Voigt, J. H. 1966. "Nationalist interpretation of Arthaśāstra in the historical writing." In S. N. Mukherjee (ed.), South Asian Affairs, no. 2: The movement for national freedom in India, 4666. Oxford: Oxford University Press.

Wagle, N. K. 1995. Society at the time of the Buddha. 2nd ed. Bombay: Popular Prakashan.

Warmington, E. H. 1928. The commerce between the Roman Empire and India. Cambridge: Cambridge University Press.

Wheeler, R. E. M. 1954. Rome beyond the imperial frontiers. London: Bell.

Wheeler, R. E. M., A. Ghosh, and K. Deva. 1946. "Arikamedu: An Indo-Roman trading station on the east coast of India." Ancient India 2, 17-124.

Wink, A. 1991. Al-Hind: The making of the Indo-Islamic world. Vol. 1, Early medieval India and the expansion of Islam 7th-11th centuries. Leiden: Brill.

Yelle, R. A. 2013. The language of disenchantment: Protestant literalism and colonial discourse in British India. Oxford: Oxford University Press. 
